\title{
Humanististen tieteiden omin käsitettävissä oleva rationaliteetti: Innovaatio vai vaaliminen?
}

\author{
Vesa Suominen \\ Oulun yliopisto
}

Informaatiotutkimuksen yliopistonlehtori Vesa Suominen jäi eläkkeelle ja piti läksiäisluentonsa 1.2.2017 Oulun yliopistossa.

Asiasanat: humanistiset tieteet; kirjastot; filosofia; kirjastonhoitajuus; rationaliteetti

Kun Aalto-yliopistoa alettiin kutsua innovaatioyliopistoksi, ajattelin, että mahtuuhan joukkoon yksi tuommoinenkin. Mutta kun koko yliopistolaitosta alettiin käsitellä osana "innovaatiojärjestelmää" (vrt. esim. Hautamäki, Ståhle, Oksanen, \& Tukiainen, 2016), tilanne oli jo pahempi. Suomalaiselle tiede- ja yliopistopolitiikalle on viime vuosikymmeninä ollut ominaista syvä sivistymättömyys tieteenalojen perustavanlaatuisen erilaisuuden suhteen. 
En lainkaan vähättele vaikkapa tekniikan tai luonnontieteiden merkitystä. Ongelma syntyy, jos (ja kun) niiden logiikka omaksutaan tai pakotetaan ikään kuin itsestäänselvyytenä kaiken tieteellisen ja opillisen rationaliteetin malliksi ${ }^{1}$. Pyrin seuraavassa osoittamaan, miten voimme käsittää humanististen tieteiden omimman rationaliteetin vaalimisen käsitteen kautta - ilman vähäisintäkään vetoamista nostalgiaan. Soveltamisesta poiketen ja sitä loogisesti edeltäenkin vaaliminen liittyy sen persoonan ja niiden yhteisöjen konstituoitumiseen, jotka ylimalkaan saattavat asettaa jotain tavoitteita, joiden toteuttamiseksi teknisesti eli toivottujen vaikutusten ja vaikkapa innovaatioiden tuottamiseksi sovellettava tieto voisi olla arvokasta. ${ }^{2}$

\section{Eläköityvän lyhyt yliopistollinen henkilöhistoria}

Eläköitymisluennossa on ehkä paikallaan aloittaa muutamalla maininnalla omasta tiestäni yliopistossa, joka alkoi 1970-luvun alussa, ennen kirjastotieteen ja informatiikan opintojen aloittamista, vuoden kestäneillä suomen kielen opinnoilla. Tuona lyhyenä jaksona jo ehti syntyä pinttynyt, vaikkakin ehkä luonteeltaan hieman esteettinenkin mieltymys lingvistien tapaan esittää asioita, mikä näkyi sitten 1980- ja 1990-luvuilla semiologia- ja strukturalismiharrastuksissani.

Suomalaisessa yliopistomaailmassa eli 1970-luvun lopulla ja 1980-luvulla vilkas "tieteenala-analyysi", osin FYTT-prosessiin (filosofisten ja yhteiskuntatieteellisten tutkintojen uudistamien), sittemmin myös sivistysyliopistohengen elähdyttämänä3 . Omaan pyrkimykseeni kirjastotieteen ja informatiikan tieteenala-analyysin suhteen liittyi kiinnostukseni luokituksiin, joiden opin olevan yksi dokumentaatiokielten laji, mikä sitten löysi vastakaikua varhaisista suomen kielen opinnoista. Ajatuksiini vaikuttivat $\mathrm{mm}$. Esa Itkosen (silloin erityisesti Itkonen, 1981) pohdinnat

Nähdäkseni yliopiston ytimenä pitäisikin olla tiedekuntien, koska ne - jos käsite otettaisiin vakavasti - edustavat perustavalla tavalla erilaisia rationaliteetteja tieteen ja oppineisuuden piirissä. Provokatiivisesti ajattelisinkin, että valtio saisi tehdä tulossopimuksiaan tiedekuntien kanssa. Kun raha kulkisi tiedekuntien kautta, ne sitten voisivat yhdessä hyvin vaikkapa ostaa alihankkijalta ja tarvittaessa kilpailuttaa keskushallinnon yliopistolleen.

2 Steven Laporte (2017) arviossaan kirjastani About and on behalf of scriptum est (Suominen 2016) käyttää huomattavan osuuden tekstistä itseisarvon (value in itself) ja instrumentaalisuuden sekä näiden suhteen pohdintaan. Tässä hänen arvionsa menee ikävästi harhateille, koska minulle juuri konstitutiivinen, ei itseisarvo, on se käsite, jonka kautta näen mahdolliseksi mielekkäästi haastaa kaikenkattavasti instrumentalistisia ajatustapoja.

3 Minulla on jokseenkin elävä mielikuva siitä, kun sivistysyliopisto tuli Tampereelle. Tuolloin Jyväskylässä työskennelleet Matti Juntunen ja Lauri Mehtonen tulivat eräänä iltana järjestettyyn yleisötilaisuuteen kertomaan uutta sanomaa, joka tuntui kuin hetkessä muuttavan kaiken. FYTT, joka vielä eilen oli ollut edistyksellisen yliopistopolitiikan kukkanen, muuttui hetkessä kirosanaksi. Kovimmatkin jäät tuntuivat sulavan, kun opiskelijat vihdoin pohtivat omaa asiaansa - lääkärien proletarisoitumiskehityksen sijasta. 
"autonomisesta kielitieteestä" ja Tarmo Malmbergin (1984) kriittiset kirjoitukset tiedotustutkimuksen piirissä. Toinen 1980-luvun merkittävä käänne kohdallani oli kiinnostumiseni dokumentaation käsitteeseen, joka näyttäytyi minulle monin tavoin konkreettisempana verrattuna informaatioon. Kun kirjastotieteen ja informatiikan ja sittemmin informaatiotutkimuksen suomalainenkin valtavirta kulki kohden yleistä informaatiopuhetta, oma tieni vei kohden dokumentaation käsitteen pohdintaa ja kirjasto säilyi keskeisimpänä kiinnostuksen kohteenani tässä kentässä.

Vielä nimenomaan strukturalistisen semiologian - mieluummin kuin muodikkaamman semiotiikan - ja toisaalta dokumentaatiosta ja dokumentista - mieluummin kuin informaatiosta - puhumisen kesken on pieni, ehkä vain viitteellinen ja hieman epämääräinenkin, mutta sellaisenaankin huomionarvoinen yhteys: puhe dokumenteista ja strukturalistinen semiologia johtavat ajatusta objekteihin ja rakenteisiin, kun taas puhe informaatiosta ja semiotiikan tuolloin ja vieläkin muodikkaammat, hyvin yleisesti peirceläisiksi luonnehdittavat virtaukset johtavat luontevasti pohtimaan ja tutkimaan prosesseja. Kerettiläisen rooli suhteessa valtavirtoihin alkoi hahmottua tässäkin, vaikka ehkä juuri tätä ei ole niin tunnistettukaan siinä piirissä, missä kerettiläisyys varsinaisesti tuli osakseni. Ei niin, etten tahtoisi puhua prosesseista, vaan niin, että halusin kyseenalaistaa prosessinäkökulman hegemoniaa ja puhua myös objekteista, minkä näkökohdan merkitys valottuu ehkä hieman lisää tuonnempana.

Ajatukselleni humanististen tieteiden ja kirjaston rationaliteettien samansuuntaisuudesta toi vankempaa perustaa haluni saada hiukan elämää strukturalistisen "erojen järjestelmien" ympärille, mikä rohkaisi minua ottamaan ensiaskelia hermeneutiikan piirissä 1990-luvun lopulla. Strukturalismin pohjalta luonteva lähtökohta oli ranskalainen hermeneutikko ja eksegeetti Paul Ricoeur ja hänen tapansa nähdä strukturaalinen analyysi varsinaisen hermeneuttisen appropriaation välivaiheena. Tässä esityksessä keskeisen vaalimisen rationaliteetin kannalta keskeisempi on kuitenkin saksalainen hermeneutikko Hans-Georg Gadamer.

Kirjaston käsittämisen tai kirjasto-opin kannalta ajatus looginen rakenne alkoi hahmottua seuraavaan tapaan. (i) Kirjastossa (ja kirjallisuudessa) erittäinkin kohtaamme merkkejä, mikä johtaa semiologiaan (Ferdinand de Saussure ja minulla erityisesti Louis Hjelmslev). (ii) Olemisemme on oleellisesti traditioissa elämistä, mikä ajatus löytää perustaa Gadamerin hermeneutiikasta ja siinä erityisesti "auktoriteetin ja tradition rehabilitaation" teemasta. (iii) Merkit ja merkkien järjestelmät (synkronia \& strukturalismi) elävät myös traditioina (diakronioina), ja konstituoivat osaltaan traditioita, mikä punoutuu Ricoeurin ideaan strukturaalisesta välivaiheesta, mutta sittemmin myös poliittisen teorian ja filosofian teemoihin - yli senkin, 
mitä löydämme Ricoeurilta. ${ }^{4}$

\section{Inhimillinen tutkimuskohde vs. tradition vaaliminen?}

Matti Juntusen ja Lauri Mehtosen (1977) teos Ihmistieteiden filosofiset perusteet oli 1980-luvulla kovasti siteerattu teos ja siinä jo nimekkeessä esiintuotu ihmistieteen käsite runsaasti käytetty käsite. Huolimatta tuon käsitteen hyvistä intentioista Juntusella ja Mehtosella näen sen muodostuneen myöhemmin eräissä suhteissa myös sudenkuopaksi, joka on osaltaan johtanut humanististen tieteiden omimman rationaliteetin hämärtymiseen, samoin kuin yhteiskuntatieteille merkityksellisten aidosti poliittisten ja esimerkiksi ideologiakriittisten kysymyksenasettelujen katoamiseen. Kun ihmistieteen ainoaksi kriteeriksi tulee, että kyse on jotenkin ihmisistä, on aivan liian helppoa edetä muilta osin puhtaasti teknisen rationaliteetin pohjalta ja redusoida niin humanistiset tieteet kuin yhteiskuntatieteetkin pelkiksi sosiaaliteknologisen innovaatiotyön apulaisiksi.

Nimenomaan humanististen tieteiden ominaisluonteen näen rakentuvan vaalimisen intressin ja rationaliteetin kautta - mieluummin kuin tutkimuksen ihmisiin kohdentumisen. Vaikka vaaliminen saattaa näyttäytyä lähinnä nostalgian motivoimalta käsitteeltä, siitä ei tässä ole missään nimessä kysymys. Voimme ajatella seuraavaan tapaan tradition, nostalgian ja järjen suhteita. Nostalgis-konservatiivisesti voisimme ajatella Sinuhen tapaan, että "näin on aina ollut, näin tulee aina olemaan ja näin on hyvä". Järjen kautta kuitenkin ja ilman vähäisintä nostalgiaa - ja jos otamme vakavasti ajatuksen ihmisen olemisen ja tiedonkin sosiaalisuudesta - yhteisen pätevyyden mitan pitää olla tullut yhteiseksi. Yhteinen tietämisemme, käsittämisemme ja ymmärryksemme voivat nimittäin nojata vain siihen, mikä on tullut yhteiseksi. ${ }^{5}$ Lopulta, yhteinen ymmärrys monissa suhteissa voi olla parempaakin kuin

Pitkän aikaa koin itse asiassa kiusallisiksi tutkintojeni nimekkeet (yhteiskuntatieteiden kandidaatti ja lisensiaatti, joista pääsin eroon väiteltyäni Oulussa filosofian tohtoriksi). En oikein osannut pitää merkityksellisesti yhteiskuntatieteinä kirjastotiedettä ja informatiikkaa tai informaatiotutkimusta sellaisina kuin näin ne Suomessa eivätkä muutkaan opintoni (filosofia siinä vaiheessa, taidehistoria ja musiikkitiede) olleet varsin yhteiskunnallisia.

5 Tätä nimenomaan voimme havainnollistaa rationaalisen keskustelun ideaalilla, jossa keskustelu etenee vetoamisin yhteisesti tunnustettuihin tai yhteisesti tunnustettaviin premisseihin yhteisymmärrystä tavoitellen, ei niinkään pyrkien muulla tavoin vaikuttamaan toisen mielipiteisiin (vs. viestintä-tutkimuksen nykypainotukset; vrt. Habermas (1984, s. 286-) ja kommunikatiivinen vs. strateginen rationaalisuus). Ainahan eivät sellaiset rationaaliset keskustelut tietenkään toteudu tai niille ei ehkä ole edellytyksiäkään. Sisällissotiakin syttyy! Tässä mielessä sivistyksellä voi olla instrumentaalistakin merkitystä - tai merkitystä osana paremman ja rationaalisemman yhteiselämän konstituutiota, sen eräänlaisena infrastruktuurina, jonka luomisella ja kehittämisellä voidaan edistää parempaa yhteiskuntaelämää. 
yksilön omat aivoitukset ja siksikin traditiota kannattaa kuunnella, vaikkei sen kanssa välttämättä tarvitse olla samaa mieltä. Näistä näen muotoutuvan humanististen tieteiden omimman vaalimisen rationaliteetin, jonka itse asiassa saatamme löytää momenttina muillakin tieteenaloilla: Fysiikallakin on historiansa ja traditionsa ja ainakin tuoreimmilla niistä on perustavaa merkitystä fysiikan käytännöissä. Ei voi puhua eikä ajatella fyysikko ilman fysiikan kieltä.

Gadamerilla näemme tämän ajatustavan - tai perustuksen hänen juhlalliselle kommentilleen, että "Historia ei itse asiassa kuulu meille, vaan me kuulumme sille" - muotoutuvan seuraavaan tapaan:

Kauan ennen kuin ymmärrämme itsemme itsetutkistelun prosessissa, ymmärrämme itsemme itsestään selvällä tavalla perheessä, yhteiskunnassa ja valtiossa, joissa elämme. [...] Yksilön itsetietoisuus on vain värinää historiallisen elämän suljetuissa ympyröissä. Tämän vuoksi yksilön ennakkoluulot, paljon enemmän kuin hänen arvostelmansa, muodostavat hänen olemisensa historiallisen todellisuuden. (Gadamer, 1992, s. 245.$)^{6}$

Heti seuraavan luvun (Auktoriteetin ja tradition rehabilitaatio) alussa Gadamer kirjoittaa, että ennakkoluulo käsitettä on arvioitava uudelleen, "jos tahdomme tehdä oikeutta ihmisen rajalliselle, historialliselle tavalle olla olemassa. Vielä, "mikä näyttäytyy rajoittavana ennakkoluulona järjen ehdottoman itsensä rakentamisen näkökulmasta, kuuluu tosiasiassa itseensä historialliseen todellisuuteen" (Gadamer, 1992, ss. 245-246).

Paljon Gadamerin ajattelusta kiteytyy sellaisiin hieman arvoituksellisen kuuloisiin lausahduksiin kuin että "Oleminen, joka voidaan ymmärtää, on kieli” (Gadamer, 1992, s. 432) tai että "kieli puhuu meitä, paremminkin kuin että me puhuisimme kieltä” (emt., 420). Tällaisten lausahdusten merkitys avautuu ehkä parhaiten, jos otamme huomioon, mitä vastaan Gadamer argumentoi. Hän kirjoittaa "modernista tieteestä", joka "Abstrahoituneena perustavasta suhteestamme maailmaan, joka on sitä koskevan kokemuksemme kielellisessä luonteessa" tähtää metodiensa avulla ilmiöitä koskevaan varmaan tietoon":

Seurauksena tästä se tuomitsee kerettiläisyytenä kaiken tiedon, johon ei sisälly tällaista varmuutta ja joka siksi ei voi palvella kasvavaa valtaa yli sen, mitä on. Tätä vastaan olemme koettaneet vapauttaa taiteen ja historian tavan olla olemassa sekä kokemuksen, joka vastaa niitä, siitä ontologisesta ennakkoluulosta, joka sisältyy tieteellisen objektiivisuuden ideaaliin. (Gadamer, 1992, s. 433)

Kaikkien sitaattien suomennokset VS. 
Voimme sanoa Gadamerin vastustavan sitä "modernin tieteen" tieteellisyyden ideaalia, joka hävittää humanistisille tieteille luonteenomaisen tietyn välittömyyden maailman ja meidän olemisemme kesken, kielen, tradition ja niitä koskevan kokemuksemme kautta, mutta ilman asioiden kontrollointiin soveltamisen edellyttämää varmuutta ja sen edellyttämää metodisuutta. Kuvio on sellainen, että tämä olemisemme on primääriä ja esimerkiksi luonnontieteissä tai muissa tekniseen soveltamiseen tähtäävässä tiedossa ja sen etsintä on vain erityistapaus sen primäärin alla. Humanististen tieteiden rationaliteetti on kuitenkin sellainen, että kun kieli puhuu meitä, on meidän paras antaa sen puhua - ja ehkä vähän kuunnella.

Hyvin voimme myös ajatella, että kaikissa noissa erityistapauksissakin on periaatteessa kuitenkin läsnä tuo primääri, mutta se voidaan käytännössä usein - arvatenkin aivan legitiimisti - unohtaa, koska se ei ole niin merkittävää esimerkiksi teknisesti sovellettavan tiedon tuottamiselle ominaisten perimmäisten tavoitteiden kannalta. Toisissa toimissamme - erityisesti humanistisissa tieteissä ja oman käsitykseni mukaan myös kirjaston yhteydessä - tuo olemisemme primääri välittömyys on sillä tavoin pinnassa, että sen unohtaminen vieraannuttaisi ne niiden omimmasta rationaalisuudesta ja siinä mielessä veisi niistä kaiken mielen. Voimme nyt hyvin ajatella, että ennakkoluulo ja tradition auktoriteetin kuunteleminen ja sitä kautta niiden vaaliminen ovat, paitsi rationaalisuuden edellytysten ylläpitämistä, myös ja perimmältään eksistentiaalista välttämättömyyttä, ilman vähäisintäkään nostalgiaa.

Vaalimista humanististen tieteiden omimpana rationaliteettina voimme nyt ilmaista esimerkiksi siten, että olemisemme on oleellisesti "being since the past" (kuten asian voi ilmaista kätevimmin englanniksi) ja että "kukin me aloitamme vuorollamme ja aina aloitamme jotain, joka jo on" (ks. Suominen, 2016). Kun "kieli puhuu meitä", parasta, mitä voimme tehdä on, että annamme sen puhua ja koetamme kuunnella, mitä sillä on sanottavanaan. Vaalimisella tarkoitan sen kultivointia, mikä tapahtuisi joka tapauksessa, mutta voi kultivoituna tapahtua paremmin - tai suosiollisemmin, voisimme ehkä sanoa, jos olisimme oikein uskaliaita. Tämä olisikin oleellinen puoli sivistyksen (Bildung) käsitettä sellaisena kuin se esiintyy Gadamerilla.

Sivistystä sellaisenaan emme voine pitää eksistentiaalisena välttämättömyytenä, kun on olemassa niin paljon sivistymättömyyttäkin. Voinemme kuitenkin pitää sitä kasvatuksellisena ja kulttuurisena ideaalina, jolla on perustuksensa eksistentiaalisessa välttämättömyydessä. Humanistisen tieteen tietyssä mielessä välitöntä suhdetta olemiseemme voimme kuvata myös siten, että kyse ei ole niinkään soveltamista ainakaan tieteellistä selittämistä kuvaavan deduktiivis-nomologisen mallin selittämisen, ennustamisen ja manipulaation analogian mukaisesti. Paremminkin on kysymys persoonan, yhteisöjen ja niihin kuulumisen konstituoitumisesta. Tältä 
kannalta näen myös jaon perustutkimus vs. soveltava tutkimus ongelmallisena humanististen tieteiden kohdalla.

\section{Siitä tietäminen, mitä pitäisi ehkä vaalia?}

Vaikka Gadamer korostaa historian ja tradition merkitystä, hän melkeinpä kategorisesti sulkee pois historian tietona siitä, mitä on ollut, pitäen sitä mahdottomana, turhana ja jopa vahingollisena "historiallisen objektivismin" tai romanttisen hermeneutiikan tai "historismin" ilmentymänä. Kysymys on paremminkin keskustelusta sen kanssa, mitä historia on meille antanut (mikä ilmenee havainnollisesti Gadamerin ilmaisun Überlieferung kääntämisenä englanninkieliseksi fraasiksi "what history has handed down to us", ks. Gadamer (1992) passim). Hieman teknisesti hän ilmaisee tätä mm. viehättävällä käsitetriadilla, subtilitas intelligendi, subtilitas explicandi ja subtilitas applicandi. Ilmaisun subtilitas (taidon tai metodin sijasta) käytön ohella tärkeää tässä on, että Gadamerille kysymys ei ole kolmesta eri asiasta, vaan yhdestä ja yhtenäisestä hermeneuttisesta prosessista, jossa nämä kaikki ovat väistämättä ja aina mukana (Gadamer, 1992, s. 274). Soveltaminen (subtilitas applicandi) on erityisesti se momentti, jossa ilmenee historiallisen objektivismin kritiikki, jolloin itse soveltamisen käsite on tietenkin toinen kuin teknistä sovellettavuutta varten tuotetun tiedon kohdalla. Saattaisimme ehkä sanoa, että Gadamerille soveltaminen tulee hyvin lähelle osallisena olemista.

Meillä voi toisaalta olla mielekkäitä intressejä myös sen tietämiseksi, mitä on ollut. Jorma Kalela kirjoittaa: "Huolimatta kaikista lingvistisen käänteen seurauksista [...] ei ole syytä luopua rekonstruktion tavoitteesta" ja jatkaa kahdesta uhkakuvasta, jotka syntyvät, jos ei olla "reiluja" heitä kohtaan, joita tutkitaan. Ensiksikin, historiankirjoituksesta voi tulla propagandan väline, "jolloin tutkituista tulee historioitsijan pelinappuloita". Toiseksi, historiankirjoituksesta voi tulla vallitsevien ennakkoluulojen vahvistamista. (Kalela, 2012, s. 35).

Ricour kirjoittaa "filosofisen hermeneutiikan" "pakkomielteisestä radikaalisuuden tavoittelusta" ("obsessive concern with radicality"), joka johtaa sitä"nousevalle polulle" ("ascending pathway") kohden ontologiaa ja hylkäämään "alenevan polun" ("descending pathway") kohden konkreettista historiantutkimusta (Ricoeur, 1976, s. 683). Kun Gadamerilla kaikki tuntuu palautuvan historialle kuulumiseemme, Ricour'n ajattelu tässä suhteessa on kompleksisempi ja kahtalainen: kuulumisen lisäksi samalla tavoin perustava konstituentti ihmisen olemisessa on vieraantumiseenkin liittyvä etäisyys, joka - toisin kuin ajallinen etäisyys Gadamerilla ei redusoidu mitenkään pois tai ei ole mitenkään voitettavissa. Juuri tähän liittyy myös Ricoeurin ajatus strukturaalisesta analyysistä tarpeellisena välivaiheena "pitkän tien" ("la voie longue", "le cheming long") hermeneutiikassa. Heideggerin hou- 
kutuksesta huolimatta - tai "quelle que soit la force extraordinaire de seduction de cette ontologie fondamental" (Ricoeur, 1969, s. 14) - Ricoeur ehdottaa, että hermeneutiikan "pitkä tie" edellyttää - heideggirilaisen fundamnetaaliontologian rinnalle - myös "tulkinnan epistemologiaa" ("une épistémologie de l'intérpretation").

Tarkkaavainen lukija saattaa tässä vaiheessa kysyä, mitä tapahtui sille tietynlaiselle välittömyydelle, joka on ominaista Gadamerin pohjalta ajatellulle humanististen tieteiden omimmalle käsitettävissä olevalle rationaliteetille. Tähän vastaisin vedoten erilaisten rationaliteettien askellukseen ("stepping order", Suominen (2016)): Ricoeurin "pitkällä tiellä" esimerkiksi strukturaalinen analyysi on vain välivaihe, alisteinen momentti hermeneutiikan perusrationaliteetille, jonka puolestaan voimme Ricoeurillakin hahmottuvan samaan tapaan sen kanssa, mitä Gadamer esittää - vaikkakin hieman ehdollisemmaksi, koska etäisyyden ja vieraantuneisuuden ei voi olettaa redusoituvan pois. Tässä mielessä voimme hyvin puhua 'ricoeurilaisista alahuomautuksista'.

Erityisesti, kun ajattelemme kirjaston ja humanististen tieteiden rationaliteettien mahdollista yhdenmukaisuutta, tekstit ja niihin liittyvät asiat myös menneenä todellisuutena ovat merkityksellisiä. Ricoeurille (1969, s. 389) "tekstin objektiivisuus" ("lobjectivité du texte"), joka strukturaalisen analyysin kautta tulisi hahmottaa, on maailma "tekstin edessä" eli tavallaan se (kvasi-)maailma ja todellisuus, jonka teksti (tai laajemmin kirjallisuus) muodostaa ja josta se puhuu puhuessaan niistä spesifimmistä asioista, joista se puhuu. Ricoeuria ja Gadameria vertaillen on syytä huomata, että Gadamerinkin Bildung epäilemättä - ja kuin itsestään selvästi - edellyttää kirjallisen kulttuurin, ehkä kirjastonkin. Ricoeurilla kirjoitus, teksti ja kirjallisuus ovat kuitenkin huomattavasti tematisoidummin osana oppia. Ricoeuriakaan ei kuitenkaan kiinnosta maailma "tekstin takana", mihin kuuluisi mm. se todellisuus, jossa teksti syntyi, samoin kuin nk. tekijän merkitykset, jotka myös Ricoeur sulkee varsin kategorisesti ulos hermeneutiikan piiristä. Omasta puolestani en olisi tässäkään niin kategorinen.

Voisimme olla kiinnostuneita niin ricoeurilaisesta kuin muustakin merkityksen tai tekstin objektiviteetistä, koska

1. tekstikritiikki voi antaa meille uusia mahdollisia tapoja ymmärtää tekstiä niiden toisten tekstien ja niissä olevien ideoiden ja käsitteiden valossa, jotka vaikuttivat ensisijaisesti luettavana olevan tekstin syntyaikaan (on huomattava, että tämäkään ei vielä välttämättä tarkoita, että meitä kiinnostaisi luettavan tekstin alkuperäiset merkitykset tai tekijän tarkoitukset);

2. ideologiakritiikki kahdessakin merkityksessä voi edellyttää, että kiinnitämme huomiota tekstin objektiviteetteihin, yhtäältä tekstin ja sen kvasi-)maailman saattaessa koetella käsitystämme siitä, mikä on todellista tai mahdollista (vrt. 
Ricoeur, 1981, s. 94), toisaalta silloin, kun hieman marxilaiseenkin tapaan kysymme, onko tekstin 'maailmankuva' jotenkin ideologisesti vääristynyt ${ }^{7}$;

3. meillä voi olla velvoitteita kirjoittajia ja heidän (kvasi)oikeuksia kohtaan (koska kirjoittaja voi tyypillisesti olla jo kuollut ja ainakin juridisessa merkityksessä on hieman ongelmallista puhua kuolleiden varsinaisista oikeuksista), mikä voi edellyttää kiinnostusta jopa niitä menneitä olosuhteita kohtaan, joissa tekstejä on tuotettu. Ideaalisessa keskustelutilanteessa ainakin olisimme ehkä kiinnostuneita siitä, mitä kukin tahtoo tai on tahtonut sanoa. Kyse olisi siis perimmältään velvoitteesta ylläpitää tiettyä rationaalisuutta res publica literariassa (jos sallitaan pieni käsitelaina toisesta yhteydestä).

Kun kiinnostus kohdistuu tekstin tai merkityksen objektiviteetteihin tai yleisemmin siihen, mitä on ollut, voimme kuitenkin ajatella edelleen päteväksi sen, mitä Gadamer kirjoittaa. Siinä kuitenkin historialle kuulumisen ideaali muuntuu väliaikaisesti metodologiseksi ongelmaksi ja varaukseksi.

\section{Vielä sananen (suomalaisesta) informaatiotutkimuksesta}

Koska olen eläköitymässä nimenomaan informaatiotutkimuksen yliopistonlehtorin tehtävästä, lienee sopivaa lopuksi suhteuttaa esittämääni myös informaatiotutkimuksen tai yleisemmin kirjasto-, informaatio- ja dokumentaatiotutkimuksen problematiikkaan ja siihen, miten sitä on hahmotettu. Samantyyppisille, käytäntösidonnaisille opinaloille luonteenomaisesti myös kirjastotieteessä ja informatiikassa / informaatiotutkimuksessa on korostettu perustavasti erilaisten rationaliteettien, myös humanististen tieteiden "lähestymistavan" mukana oloa (ks. esim. Järvelin \& Vakkari, 1988). Ehkä perusteellisimpana pohdintana voimme pitää Savolaisen (1989) katsausta suomalaiseen 1980-luvun keskusteluun. Oireellisena saatamme kuitenkin pitää sitä, että nämä keskustelut ovat valtaosin jääneet 1980-luvulle. Luonnollista on - mutta myös kohtalokasta voi olla - sellainen itsetyytyväisyys, että kun tunnemme itsemme kovin valmiiksi, emme juuri kysele perusteitamme.

Pelkäänpä kuitenkin, että humanistisille tieteille ominaisimman rationaliteetin mahdollista merkitystä alamme kannalta on vain harvoin ymmärretty kovin perustavasti, ja itsekin olen joutunut työskentelemään sen kanssa pitkään. Tässä suomalainen informaatiotutkimus on suomalaisen yliopisto- ja tiedepolitiikan mallioppilaana ehkä vähän tarpeettomankin tunnollinen ja kuuliainen. Uskaltaisin myös

7 Tätä valaisee erinomaisesti Albrecht Wellmerin (1971, s. 47) sattuva ja kärkevä huomautus siitä, mitä "the Enlightenment knew and hermeneutics forgets: that the 'dialogue' which (according to Gadamer) we 'are', is also a relationship of coercion and, for this very reason, no dialogue at all". 
arvella, että kykenemättömyydellä käsittää kovin konkreettisesti humanististen tieteiden ominaisinta rationaliteettia on ainakin looginen yhteys siihen vähäiseksi jääneeseen mielenkiintoon, jota suomalaiset informaatiotutkijat ovat osoittaneet kirjastoproblematiikkaa kohtaan.

\section{Lähteet}

Gadamer, H.-G. (1992). Truth and method. New York: Crossroad.

Habermas, J. (1984). The theory of communicative action. Volume 1. Reason and the rationalization of society. Boston: Beacon Press.

Hautamäki, A., Ståhle, P., Oksanen, K., \& Tukiainen, T. (2016). Vaikuttavaa tutkimusta: Kokeiluehdotuksia tutkimuksen vaikuttavuuden ja kaupallistamisen edistämiseksi. Helsinki: Työ- ja elinkeinoministeriö. http://urn. fi/URN: ISBN: 978-952-327-080-0

Itkonen, E. (1981). Kielitieteen osa-alueet ja niiden suhde toisiinsa. Teoksessa M. Heikkilä \& T. Oksala (toim.), Humanistisesta tutkimuksesta 2 (ss. 17-43). Helsinki: Gaudeamus.

Järvelin, K., \& Vakkari, P. (1988). Kirjastotiede ja informatiikka - tiedon hankinnan tiede. Kirjastotiede ja informatiikka, 7(1), 18-32. http://journal.fi/inf/article/view/1338

Kalela, J. (2012). Making history: the historian and uses of the past (s. 196). Palgrave Macmillan.

Laporte, S. (2017). About and on Behalf of Scriptum Est by Vesa Suominen. Journal of Documentation, 73(1), 181-184. https://doi.org/10.1108/JD-09-2016-0115

Malmberg, T. (1984). Viestinnän teoria ja tutkimus. Tampere: Tampereen yliopisto.

Ricoeur, P. (1969). Le Conflit des Interprétations Essais D’Herméneutique. Paris: Éditions du Seuil.

Ricoeur, P. (1976). History and Hermeneutics. The Journal of Philosophy, 73(19), 683. https://doi. org/10.2307/2025627

Ricoeur, P. (1981). Hermeneutics and the human sciences : essays on language, action, and interpretation. (J. B. Thompson, toim.) (s. 314). Cambridge University Press.

Savolainen, R. (1989). Kirjastotieteen ja informatiikkan intressit: 1980-luvun keskustelun arviointia. Teoksessa M. Viljakainen-Tiittanen (toim.), Kirjastotiedettä ja informatiikkaa tekemässä (ss. 2759). Kirjastotieteen ja informatiikan yhdistys.

Suominen, V. (2016). About and on behalf of Scriptum est : the literary, bibliographic, and educational rationality sui generis of the library and librarianship on the top of what literature has produced. University of Oulu. http://urn.fi/urn:isbn: 9789526212302

Wellmer, A. (1971). Critical theory of society. New York: Herder \& Herder. 